\title{
S114035
}

\section{衝撃を受けた際のテーパーシールにおける流体表面の挙動* (テーパーシールの姿勢及び表面張力の接触角の影響)}

\author{
楊 偉紅 ${ }^{* 1}$, 平尾 明洋 ${ }^{* 2}$

\begin{abstract}
Behavior of fluid surface in a tapered seal when subjected to a shock (Influence of the orientation of a tapered seal and the contact angle of surface tension)
\end{abstract} \\ Weihong YANG ${ }^{* 1}$ and Akihiro HIRAO \\ ${ }^{* 1}$ R\&D Department, Engineering Support Division, Minebea CO., LTD. \\ 1-1-1, Katase, Fujisawa-shi, Kanagawa-ken, 251-8531 Japan
}

To clarify the mechanism of tapered seals located at the end of fluid dynamic bearings used in spindle motors for hard disk drives, the behavior of the fluid surfaces of the seals when the spindle motors are subjected to shocks is analyzed and solved. As a continuation of the last paper this paper discusses the influence of motor orientations and surface tension contact angles on the behavior of fluid seal surfaces. The relationship between oil leakage and motor orientations is affected by the responses of the rotor in the motor. When the responses of rotors are assumed to be the same in the vertical orientation and in the horizontal orientation, oil leakage more likely appears in the horizontal orientation. Contact angles tend to be larger when the fluid surface is moving. Accordingly the seal design should take into account of the moving speed of the fluid surface. To prevent oil leakage from the seal, it is effective to reduce the vibration amplitude and the moving speed of the fluid seal surface by providing an adequate clearance and length of the seal and higher stiffness and stronger damping of bearings.

Key Words : Tapered seal, Fluid seal, Fluid dynamic bearing, Hydrodynamic bearing, Shock, Response of rotor, Inertia force, Surface tension, Contact angle of surface tension, Behavior of fluid surface, Multi-phase flow, HDD

\section{1. 緒 言}

テーパーシールは流体動圧軸受部から大気開放口に向かいテーパー状に隙間が広がる構造を持つことにより， 表面張力と毛管効果を利用して潤滑油の漏れを防ぐ装置である.HDD のスピンドルモータに使われる流体動圧軸 受には潤滑油漏れを防ぐためにテーパーシールが流体軸受端部に設けられている. HDD を使用する機器には可搬 性を要求されるものも多く，スピンドルモータが定常回転している時だけでなく，外部から衝撃を受けた際にも 流体軸受からの潤滑油の漏れを防ぐことができる設計となっていなければならない．その潤滑油漏れを防ぐため のテーパーシールのメカニズムを解明するため, 前報(1)ではスピンドルモータが衝撃を受けた際のシールにおけ る液面の挙動を回転体の応答, 流体に作用する慣性力, 重力及び表面張力などの影響を考慮し, 混相流として理 論的に検討し，VOF 法及びMDM 法を使った数值解析方法を提示した. モータが衝撃を受けた際のシール夜面の 挙動を回転体の応答・シャフトの偏心・テーパーシールの形状・潤滑油の洏れ止め剤の影響に注目して解析した. シール漏れに最も影響するのは衝撃に応答するシール液面の軸方向の移動速度と振幅であり, そのシール液面の 移動速度と振幅は衝撃加速度のほか, 回転体の応答, シャフトの偏心及び夜面でのシール隙間に依存することを 指摘し，潤滑油漏れの対策を提案した．前報に続き，本報は衝撃を受けた際のスピンドルモータの姿勢拉よび表 面張力接触角の速度依存性を考慮した動的接触角がシール液面の挙動に及ぼす影響を数值解析によって解明した。 また, シールが潤滑油漏れを起こすときのメニスカスの様子を解明した。

\footnotetext{
${ }^{* 1}$ 正員, ミネベア株式会社（テ251-8531 神奈川県藤沢市片瀬 1 丁目 1 番 1 号)

*2 非会員, ミネベア株式会社 (テ153-8662 東京都目黒区下目黒 1 丁目 8 番 1 号アルコタワー19 階)

E-mail: whngyng@minebea.co.jp
} 


\section{2. 衝撃を受けた際のテーパーシールにおける液面の挙動}

\section{$2 \cdot 1$ 衝撃を受けた際のテーパーシールにおける液面挙動の解析モデル}

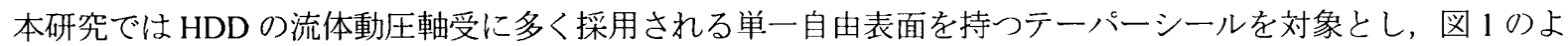
うな簡単な流体動圧軸受装置モデルを使った，スピンドルモータの置かれる姿勢によって，シールの大気開放口 が上向き（図 1a），下向き（図 lb）及び水平（図 1c）姿勢がある. 解析方法は前報で提示したものと同じ，スピ ンドルモータが衝撃を受けた際のシールにおける液面挙動を回転体の応答, 流体に作用する慣性力, 重力及び表 面張力, 軸受の圧力などの影響を考慮し，VOF 法及びMDM 法を使った数值解析方法である．以下の解析結果は スピンドルモータが受けた衝撃加速度をすべて下向きの $\ddot{y}=-1000 \mathrm{~g} \sin (500 \pi t)(\mathrm{t}=0-2 \mathrm{~ms}), \ddot{y}=0(\mathrm{t}>2 \mathrm{~ms})$ とする.

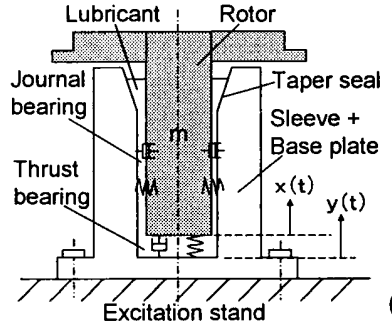

Rotating axis is in vertical direction and seal surface is facing up.

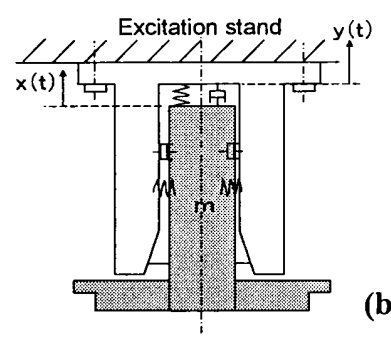

Rotating axis is in vertical direction and seal surface is facing down.

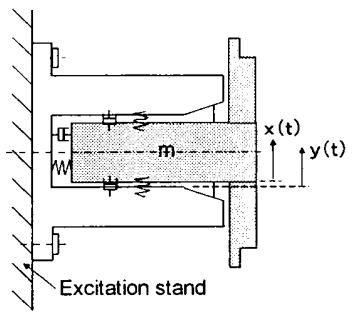

(c) in horizontal direction

Fig.1 Simulation model

\section{$2 \cdot 2$ スピンドルモータの回転軸の姿勢の影響}

図 2 は図 1(b)のようにテーパーシールの大気開放口が下向きの垂直姿勢, シャフトとスリーブの偏心率が右寄 せ 0.3 , 潤滑油温度 $80^{\circ} \mathrm{C}$, 回転体の回転速度 $20000 \mathrm{rpm}$, 表面張力接触角 $10^{\circ}$, 衝撃への回転体がスリーブに対寸 る相対応答速度を $v=0.100528 \sin (4000 \pi t)$ とした場合の時間経過におけるシール部の左右それぞれ部分のシー ル液面の挙動の断面を示寸. 左部は半径方向の最大軸受隙間と慗がるテーパーシールの断面図, 右部は半径方向 の最小軸受隙間と繋がるテーパーシールの断面図である (以下同). 赤色は潤滑油, 青色は空気を示す (以下同). スピンドルモータが垂直姿勢で衝撃を受けた際, 軸受装置は軸方向で衝撃力を受けるので, シャフトの偏心率が 変化しない. 衝撃への応答周期は $0.5 \mathrm{~ms}$ で, $\mathrm{t}=0 \sim 0.25 \mathrm{~ms}$ のとき, 回転体の応答により潤滑油を収納する体積が急 に縮小され, 潤滑油は絞り効果によって圧力が上がり, 外側へ押し出され, $\mathrm{t}=0.25 \sim 0.5 \mathrm{~ms} の$ とき, 回転体の応答 により逆に潤滑油を収納する体積が急に拡大され, 負圧が発生し, 潤滑油は内側一戻る. 図 3 はスピンドルモー 夕が水平姿勢, 回転体の回転速度, 衝撃への回転体の相対応答速度, 表面張力接触角, 潤滑油温度が共に図 2 と 同一の場合の時間経過におけるシール部の上下それぞれ部分のシール液面の挙動の断面を示す. 水平姿勢で衝撃 を受けた場合は, 軸受装置はラジアル方向で衝撃力を受けるので,シャフトの偏心率は衝撃を応答して変動する. $\mathrm{t}=0 \sim 0.25 \mathrm{~ms}$ のとき, ジャーナル軸受とシールの下半部の断面面積（潤滑油を収納する体積）が急に拡大され，同 時に, ジャーナル軸受とシールの上半部の断面面積（潤滑油を収納する体積）が急に縮小され， $\mathrm{t}=0.25 \sim 0.5 \mathrm{~ms} の$ とき,この過程が逆になる (以下の水平姿勢の場合は同). 水平姿勢のほうが垂直姿勢より応答による潤滑油のシ 一ルへの出入りが多く, 急激に変化する圧力がシールに近い. 図 2 と図 3 を比較すると, 垂直姿勢の場合はシー ル液面の振幅が小さく，水平姿勢の場合はシール液面の振幅が大きいことが分かる．また，空気を軸受内に吸い 込まないために, 即ち液面をシール内に保持させるために, 十分な潤滑油量が必要である.

図 4 と図 5 は表面張力接触角が $135^{\circ}$ ，スピンドルモータが垂直姿勢および水平姿勢の場合のシール液面の 挙動を示す. 他の条件は図 2 及び図 3 と同一である. 衝撃による回転体の相対応答速度が同一の場合, 水平姿勢 のほうが垂直姿勢より振幅が大きい. 図 5 と図 3 に比べると, 表面張力接触角が $135^{\circ}$ になると, $\mathrm{t}=0.5 \mathrm{~ms} \sim 0.75 \mathrm{~ms}$ のとき, 回転体の応答によってジャーナル軸受及びシールの下側断面が拡大され, 凸部メニスカスと凹部メ二ス カスが同時に生成し，凸部メニスカスがシール内側へ戻れず，凹部メニスカスとの距離が大きくなって，シール 
液面での圧力差と表面張力のバランスが崩れ，メニスカスが潰れる．その極端な場合には，メニスカスが破れ， 独立した液滴が発生する。

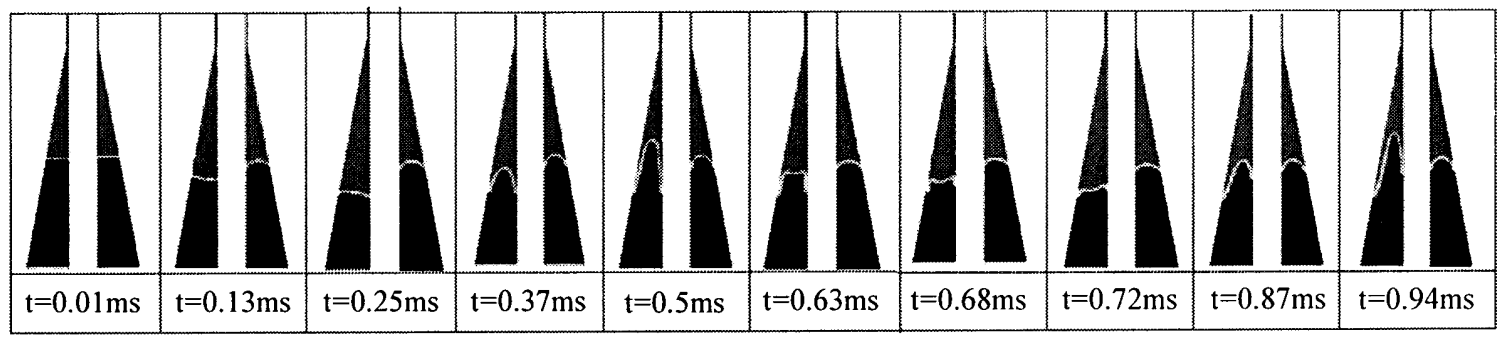

Fig. 2 Behavior of fluid surface of the seal with contact angle of surface tension 10 degree $\quad(v=0.100528 \sin (4000 \pi t))$

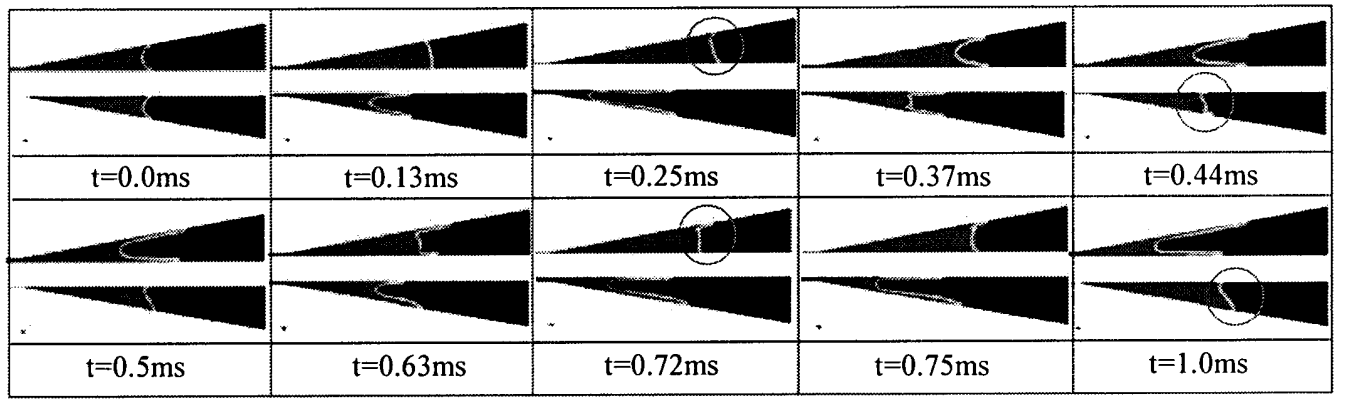

Fig. 3 Behavior of fluid surface of the seal with contact angle of surface tension 10 degree $\quad(v=0.100528 \sin (4000 \pi t)$

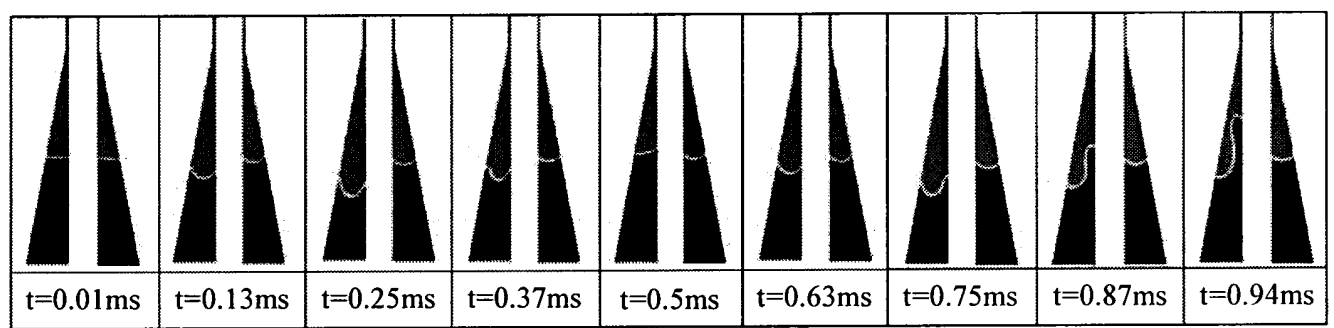

Fig. 4 Behavior of fluid surface of the seal with contact angle of surface tension 135 degree $\quad(v=0.100528 \sin (4000 \pi t))$

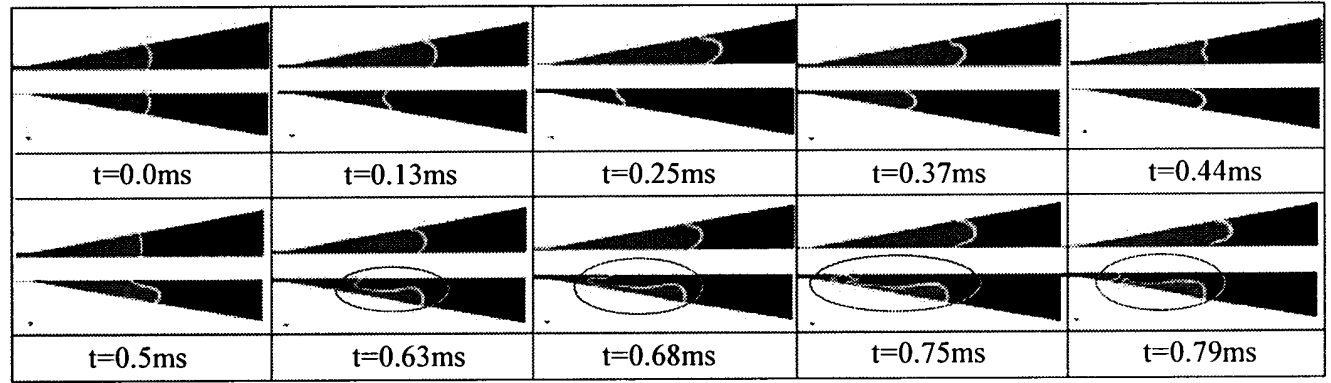

Fig. 5 Behavior of fluid surface of the seal with contact angle of surface tension 135 degree $\quad(v=0.100528 \sin (4000 \pi t))$

図 6 と図 7 はシールのテーパー角は 30 度, 表面張力接触角は $10^{\circ}$ ，垂直姿勢及び水平姿勢，他の条件は図 2 及び図 3 と同一の場合のシール液面の挙動を示寸. 衝撃による回転体の応答が同一の場合, 水平姿勢のほうが垂 直姿勢より振幅が大きい. シールのテーパー角が $30^{\circ}$ になると, テーパー面での表面張力が弱くなり, 特に水平 姿勢のシールの下側断面を注目すれば， $0.5 \mathrm{~ms} \sim 0.75 \mathrm{~ms}$ のとき，シール断面が拡大され，上述図 5 と同じように， 凹部メニスカスと凸部メニスカスが同時に生成し，凸部メニスカスがシール内側へ戻れず，凹部メニスカスとの 
距離が大きくなって, シール液面での圧力差と表面張力のバランスが崩れ，メニスカスが潰れ，潤滑油漏れにな った.

即ち，衝撃による回転体の応答が同一の場合，スピンドルモータが水平姿勢のほうが垂直姿勢よりシール液面 の振幅及び移動スピードが大きく, 潤滑油が軸受内に入ったり, 漏れたりしやすい。 また, ラジアル方向の軸受 隙間が小さいので，大きな衝撃を受けた場合，シャフトとスリーブの金属接触も発生しやすい.

一方，スピンドルモータが回転するとき，回転体の応答は軸受の剛性と減衰に依存する．多くの設計はスラス 卜軸受の剛性がジャーナル軸受の剛性より弱いので, 垂直姿勢の回転体の応答速度は水平姿勢の場合より大きい. 図 8 は, 回転体の応答速度が図 2 の倍の $v=0.201056 \sin (4000 \pi t)$, 他の条件が図 2 と同一の場合のシール液面の 挙動を示寸. 図 8 においてはシール液面の振幅が大きく, 移動速度も速いため, 凸部のメニスカスがシール内側 に戻れず，凹部のメニスカスとの距離が大きくなって,メニスカス両側の圧力差と表面張力との力のバランスが 崩れ, 潤滑油漏れになった.

即ち, 潤滑油漏れとスピンドルモータの姿勢の関係は回転体の応答に依存する．回転体の応答は軸受の剛性及 び減衰に依存するので, 潤滑油漏れを起さない流体動圧軸受を実現するためには，テーパーシールの形状や容積 だけでなく，軸受の剛性や減衰の特性に注目して設計を行う必要がある.

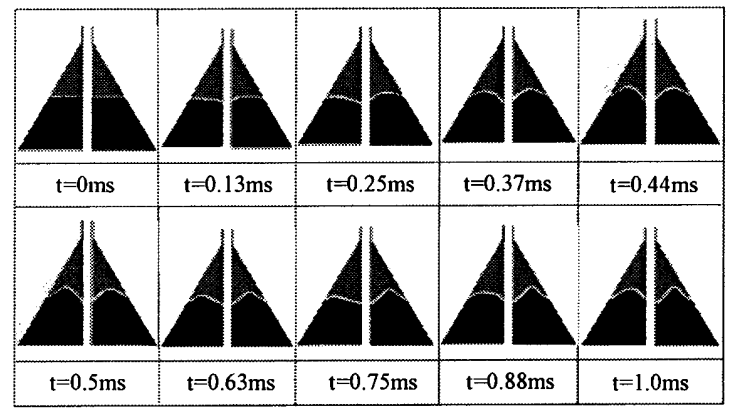

Fig. 6 Behavior of fluid surface of the seal with tapered angle 30degree and contact angle of surface tension 10 degree $\quad(v=0.100528 \sin (4000 \pi t)$

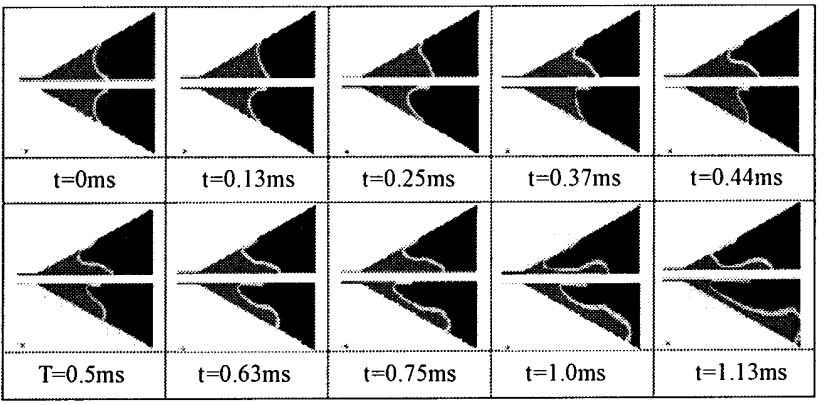

Fig. 7 Behavior of fluid surface of the seal with tapered angle 30 degree and contact angle of surface tension 10 degree $(v=0.100528 \sin (4000 \pi t))$

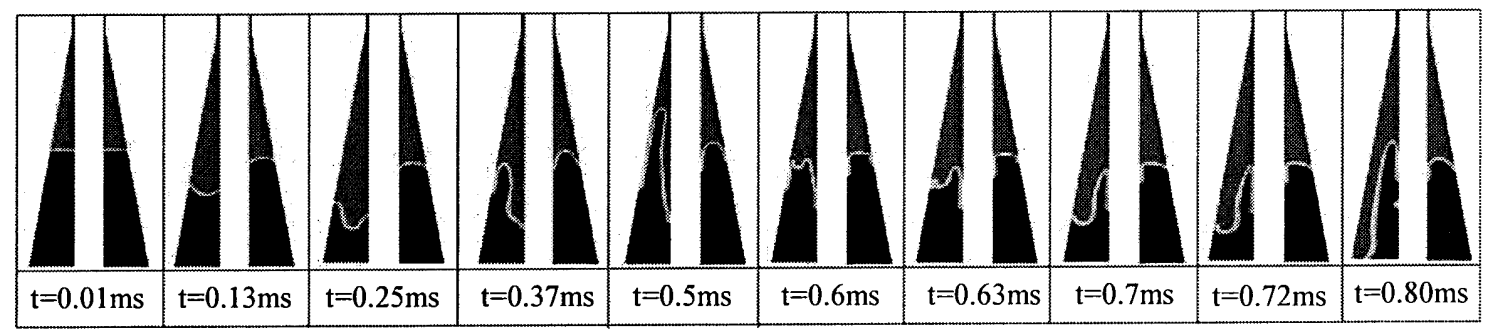

Fig. 8 Behavior of fluid surface of the seal with contact angle of surface tension 10 degree $\quad(v=0.201056 \sin (4000 \pi t)$

\section{$2 \cdot 3$ 表面張力の静的及ひ動的接触角の影留}

表面張力接触角が衝撃を受けたスピンドルモータのシール液面の挙動に与える影響は図 3, 図 5, 図 9 に示す. 図 3 は表面張力接触角度 $10^{\circ}$, 図 9 は $60^{\circ}$, 図 5 は $135^{\circ}$, 他の条件は寸べて図 3 と同一である. 表面張力の接 触角が大きくなると, 表面張力が弱くなり，シールが耐えられる液面両側の圧力差が小さくなる．接触角が $60^{\circ}$ の場合は $10^{\circ}$ の場合よりメニスカスの凸形の成分が多くなった．さらに $135^{\circ}$ になると，凹部メニスカスと凸部 メニスカスが同時に生成し，凸部メニスカスがシール内側へ戻れず，凹部メニスカスとの距離が大きくなって， メニスカスが潰れ, 潤滑油漏れになった. 即ち, 表面張力の接触角が大きくなると, 表面張力が小さくなってシ 一ル機能に不利になり, 潤滑油が漏れやすくなる。ここまでの議論は, 接触角を気液界面が壁面に対し静止して いるとき接触線に働く表面張力の接触角である静的接触角としてシミュレーションした結果である. 
しかし，壁面に対し，接触線が移動しているときには静的接触角とは異なる動的接触角となることが知られて いる(2)(3). 動的接触角とは, 固体, 液体, 気体の界面（三重線）が解進及び後退しているときの接触角である. 接 触角と三重線の速度 $v_{c}$ の関係式は次式で与えられる ${ }^{(3)}$.

$$
v_{c}=\frac{\gamma}{6 l_{c} \mu} \cdot \theta_{D}\left(\theta_{D}{ }^{2}-\theta_{E}^{2}\right)
$$

ここで， $\theta_{E}$ は静的接触角， $\theta_{D}$ は動的接触角， $\gamma$ は表面張力係数， $\mu$ は潤滑油の粘性係数， $l_{c}$ は $15 \sim 20$ 程度 の定数である. 潤滑油が $25^{\circ} \mathrm{C}$ 及び $80^{\circ} \mathrm{C} の$ 場合, 式(1)による動的接触角 $\theta_{D}$ が三重線の速度 $v_{c}$ 及び静的接触角 $\theta_{E}$ と の関係を図 10 に示す. $\theta_{D}$ は $\theta_{E}$ より大きく， $v_{c}$ は速くなると， $\theta_{D}$ が大きくなる.

即ち, 衝撃への応答によってシール液面が移動しているとき, 表面張力接触角は動的接触角になり, 液面の移 動速度によって変化する. 移動速度が速いほど, 動的接触角も大きくなり, 表面張力が弱くなって, シール液面

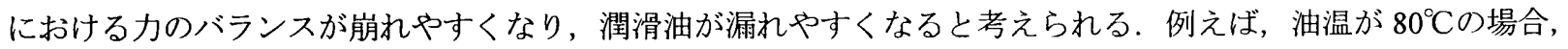
液面移動速度は $0.06 \mathrm{~m} / \mathrm{s}$ のとき, 表面張力接触角は静的接触角の $10^{\circ}$ ではなく, 動的接触角の $60^{\circ}$ になる. 従っ て, テーパーシールを設計するときは，シール液面の移動により実質的な接触角は大きくなっていることを想定 して, 安全を見たシールの設計を行う必要がある.

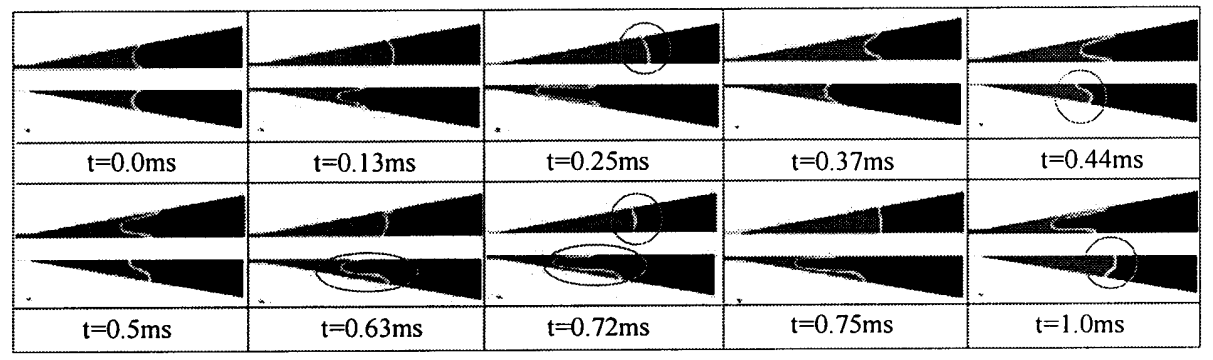

Fig. 9 Behavior of fluid surface of the seal with contact angle of surface tension 60 degree $(v=0.100528 \sin (4000 \pi t))$

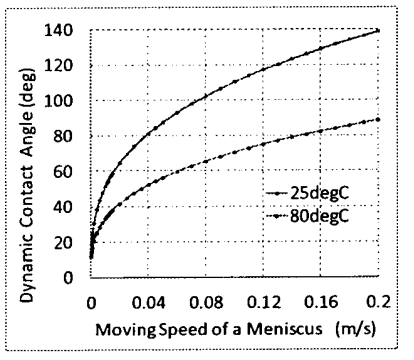

Fig. $10 \theta_{D}$ Vs. $v_{c}\left(\theta_{E}=10^{\circ}\right)$

\section{3. 結 論}

（1）衝撃を受けた際, 潤滑油漏れとスピンドルモータの姿勢との関係は回転体の応答に依存する. 水平姿勢と垂 直姿勢を比較すると，軸受の剛性および減衰が半径方向と軸方向で同一の場合には，水平姿勢のほうが潤滑 油漏孔になりやすい，半径方向の軸受剛性は軸方向より通常高いが，十分な剛性と減衰を持った軸受設計を 行う必要がある.

（2）衝撃を受けた際，シール液面が移動するため表面張力接触角は大きくなる. 回転体の応答を抑えること，シ 一ル隙間を大きくすることなどして，シール液面の移動速度と振幅を抑えることが潤滑油漏れ防止に有効で ある.

（3）シールのテーパー角をあまり大きくすると表面張力が弱くなり，シール液面での圧力差と表面張力とのバラ ンスが崩れメニスカスが潰れやすくなるため, シール部の容積はシール長さにより確保することも考慮すべ きである.

\section{文献}

（1）楊偉紅，平尾明洋，“流体動圧軸受端部に設けられたテーパーシールに関するメカニズムの解明（衝撃を受けたときのテ 一パーシールにおける流体表面の挙動)”, 日本機械学会 2011 年度年次大会 DVD 論文集, 2011, Sep. (講演番号:S112032).

（2）松田京子, 松岡広成ら, “動的接触角を考慮した液体メニスカス架橋の力学特性解析”, 日本機械学会第 2 回マイクロ・ ナノ工学シンポジウム講演論文集, 2010, Oct., (講演番号:053).

(3) 古庄康裕, 松並弘ら, “動的接触角を考慮した気液混相流の数值解析”, 第 23 回数值流体力学シンポジウム, 2009, A5-5. 